\title{
O inventário como ferramenta de reconhecimento e preservação do patrimônio cultural das comunidades rurais de Santo Antônio do Palma/RS, Brasil
}

The inventory as a toll for the recognition and preservations of the cultural heritage of rural communities in Santo Antônio do Palma/RS, Brazil

El inventario como herramienta para el reconocimiento y preservación del patrimonio cultural de las comunidades rurales em Santo Antônio do Palma/RS, Brasil

GIGLIOLI, Adilson ${ }^{1}$ JUNIOR, Dirceu Piccinato ${ }^{2}$ KUJAWA, Henrique Aniceto ${ }^{3}$

Faculdade Meridional, Escola Politécnica, Programa de Pós-Graduação Stricto Sensu em Arquitetura e Urbanismo, Santo Antônio do Palma, Brasil.

1 adilsongiglioli@gmail.com ORCID ID: 0000-0002-6193-2325

2dirceu.piccinato@imed.edu.br ORCID ID: 0000-0001-5153-0931

3henrique.kujawa@gmail.com ORCID ID: 0000-0001-9990-9414 


\title{
Resumo
}

O patrimônio cultural é objeto de interesse de diversos mecanismos e ferramentas que visam o seu registro, reconhecimento, preservação, bem como sua promoção, entre esses mecanismos, o inventário é um dos recursos comumente utilizados para se atingir esses fins. Assim, este artigo tem por objetivo inventariar e debater acerca da atual condição do patrimônio material e imaterial, sobretudo, do saber-fazer, presente nas comunidades rurais de descendentes de imigrantes italianos e poloneses no município de Santo Antônio do Palma, Rio Grande do Sul, Brasil. A metodologia adotada para a pesquisa constituiu-se a partir de uma abordagem conceitual bibliográfica e a estruturação de uma ficha de inventário do patrimônio material e imaterial, a qual foi preenchida com os dados coletados durante as pesquisas de campo. A partir da coleta dos dados e da realização das fichas foi possível obter um panorama do atual cenário cultural do município supracitado, onde avaliou-se como relevante os esforços que vem sendo feito pelos atores locais nos últimos anos, a fim de manter vivas as memórias, as histórias, assim como o saber-fazer herdados de seus antepassados. São empenhos que contribuem para a manutenção da identidade local, bem como podem contribuir para o desenvolvimento cultural dessas comunidades.

Palavras-Chave: Patrimônio cultural; imigração italiana; imigração polonesa; saber-fazer; inventário patrimonial

\begin{abstract}
The cultural heritage is the object of interest for several mechanisms and tools that aim at its registration, recognition, preservation, as well as its promotion, among these mechanisms, the inventory is one of the resources commonly used to achieve these ends. Thus, this article aims to inventory and debate the current condition of material and immaterial heritage, especially know-how, present in rural communities of descendants of Italian and Polish immigrants in the municipality of Santo Antônio do Palma, Rio Grande do Sul, Brazil. The methodology adopted for the research was based on a conceptual bibliographic approach, the structuring of a material and immaterial patrimonial inventory sheet, which was filled in with the data collected during the field research. From the collection of data and the realization of the forms, it was possible to obtain an overview of the current cultural scenario of the aforementioned municipality, where the efforts that have been made by local actors in recent years in order to keep the memories alive, have been evaluated as relevant. the stories, as well as the know-how inherited from their ancestors. These are commitments that contribute to the maintenance of local identity, as well as they can contribute to the cultural development of these communities.
\end{abstract}

Key-Words: Cultural heritage; Italian immigration; Polish immigration; Know-how; Heritage inventory

\section{Resumen}

El patrimonio cultural es objeto de interés de diversos mecanismos y herramientas que tienen como objetivo su registro, reconocimiento, preservación, así como su promoción, entre estos mecanismos, el inventario es uno de los recursos comúnmente utilizados para lograr estos fines. Así, este artículo tiene como objetivo inventariar y debatir la condición actual del patrimonio material e inmaterial, especialmente el saber hacer, presente en las comunidades rurales de descendientes de inmigrantes italianos y polacos en el municipio de Santo Antônio do Palma, Rio Grande do Sul, Brasil. La metodología adoptada para la investigación se basó en un enfoque bibliográfico conceptual, la estructuración de una hoja de inventario patrimonial material e inmaterial, que se completó con los datos recolectados durante la investigación de campo. A partir de la recolección de datos y la realización de los formularios, fue posible obtener un panorama del actual escenario cultural del referido municipio, donde se encuentran los esfuerzos que han realizado los actores locales en los últimos años con el fin de mantener viva la memoria, Se han evaluado como relevantes las historias, así como el saber hacer heredado de sus antepasados. Estos son compromisos que contribuyen al mantenimiento de la identidad local, así como pueden contribuir al desarrollo cultural de estas comunidades.

Palabras clave: Patrimonio cultural; inmigración italiana; inmigración polaca; saber hacer; inventario del patrimonio 


\section{Introdução}

Ao tratarmos da dimensão patrimonial, seja ela material ou imaterial, simultaneamente abordar-se-á as histórias e as memórias sociais que estão associadas a determinado artefato ${ }^{1}$ histórico. Para Pierre Nora (1981), a memória é dinâmica, é vida sendo expressa pelos grupos sociais e está em constante processo evolutivo, aberta ao debate das dimensões da lembrança, mas também sujeita ao esquecimento, vulnerável a todo tipo de usos e manipulações, sensível ao tempo e as revisões.

Realçando as relações intrínsecas entre os artefatos patrimoniais, a memória e a identidade cultural, Castriota (2009) afirma que ao lado dos bens móveis e imóveis, aqueles de criação individual ou coletiva, componentes do acervo artístico, também se consideram como parte do patrimônio cultural de um povo ou de determinada comunidade, uma outra espécie de bens, o "saber-fazer" popular, os quais estão inseridos na dinâmica viva do cotidiano.

Para Edelweiss (2016), o meio em que vivemos atua como um cenário de um espetáculo e dele deixase registrar as marcas da passagem do tempo. É importante que o indivíduo constitua uma ideia coerente do que é o patrimônio cultural, sendo esse conjunto de bens, materiais e imateriais, elementos relevantes para a construção da memória e identidade coletiva.

Assmann (1995, apud Weber; Malta, 2010) atribui seis características à memória cultural: a relação com o grupo, que produz a identidade; a capacidade de reconstrução, pois a memória não pode preservar o passado, cada era reconstrói sua memória dentro do sistema de referência contemporâneo; a transmissão da herança cultural necessita de objetos que cristalizem significados para os integrantes do grupo; necessidade de organização na transmissão da memória; compromisso, pois, ela forma a autoimagem de um grupo e um claro sistema de valores e diferenciações que estruturam a fonte cultural do conhecimento e dos símbolos.

Em suas concepções, Weber e Malta (2010, p. 120) defendem que a memória cultural serve para estabilizar a autoimagem da sociedade. Através de sua herança cultural uma sociedade (ou grupo) se torna visível a si mesma e aos outros. Sendo assim, a memória se torna um elemento essencial na construção das identidades culturais. "Através da memória cultural, portanto, é que os grupos constroem sua identidade, preservam suas tradições, ritos e costumes, elaboram a representação de si mesmos e dos outros, bem como reforçam seu sentimento de pertencimento, adesão".

Na perspectiva, com o intuito de contribuir para o registro, preservação e salvaguarda da memória e do saber-fazer das comunidades de imigrantes italianos e poloneses que vivem em comunidades rurais no pequeno município de Santo Antônio do Palma, Rio Grande do Sul, Brasil, o presente artigo se debruça sobre seu objetivo principal, que é o de inventariar o patrimônio imaterial do saber-fazer destes grupos sociais, ou seja, auxiliar na reconstrução das histórias e memórias, que são importantes subsídios para a reafirmação da identidade cultural dessas duas comunidades, sobretudo as rurais, pois é no cotidiano destas famílias de descendentes de imigrantes, que ainda são preservados alguns dos saberes herdados de seus antepassados.

Não somente como uma ferramenta de registro e preservação, o presente estudo ganha relevância na perspectiva de que o processo de inventariamento, além de salvaguardar as características culturais, pode a longo prazo servir como um mecanismo de transmissão do saber-fazer, das histórias, memórias, de modo geral, da identidade cultural das comunidades. É justamente nesse aspecto, o da transmissão, que se concentra uma das principais problemáticas a respeito da manutenção da identidade cultural.

\footnotetext{
${ }^{1}$ O termo artefato, segundo Carlos A. C. Lemos (2013), é o que talvez devesse ser utilizado para designar essa profusão de elementos, objetos, isto é, denominando desde um simples machado de pedra até uma edificação religiosa ou civil, ou até mesmo uma cidade.
} 
Fundamentada com base no objetivo proposto e na problemática identificada, a metodologia adotada para o desenvolvimento deste artigo estruturou-se no desenvolvimento de um modelo de ficha de inventário patrimonial imaterial, que teve como base referencial as obras: Inventário Nacional de Referências Culturais: Manual de Aplicação (IPHAN, 2000), Educação Patrimonial: Inventários Participativos (IPHAN, 2016) e o SICG - Sistema Integrado de Conhecimento e Gestão (IPHAN, 2013).

A realização dos inventários se deu através de pesquisa de campo, de forma participativa entre pesquisadores e atores locais, levando em conta todos os cuidados necessários devido ao cenário que se encontra, ocasionado pela pandemia do Covid-19. Foram estudadas para a elaboração deste texto duas propriedades rurais, sendo uma de descendência de imigrantes italianos e a outra de descendentes poloneses. A justificativa para a escolha de ambas propriedades se deu pelo fato de que as mesmas conservam ainda em seu cotidiano alguns dos saberes herdados de seus antepassados e que são praticados de forma rotineira, não apenas eventualmente ou por finalidades turísticas.

Para a estruturação das fichas de inventário levou-se em conta aspectos técnicos, tanto para os bens materiais como os imateriais, instâncias morfológicas de conservação, de reuso e culturais. Abordouse para os artefatos materiais e imateriais, como o saber-fazer, a história desses bens, quais são os fatores de preservação e o estado de degradação, isto é, conjuntura que influencia para seu risco de desaparecimento, assim como, análise da paisagem cultural do entorno. Particularmente, quanto aos aspectos imateriais, utilizou-se de entrevistas semiestruturadas que foram gravadas, além de filmagens e fotografias. O intuito é de compreender quais são os significados das manifestações culturais ou expressões folclóricas, as etapas, os métodos, os trajes, os rituais, ou seja, o conjunto de informações pertinente à pesquisa. Outro aspecto relevante pontuado pelos procedimentos metodológicos é a transmissão do conhecimento entre as gerações.

Ferrão (2007) destaca que os estudos sobre as comunidades rurais no Brasil evoluíram muito nos últimos anos. Ao se tratar do meio rural, remete-se a ideia de uma paisagem rudimentar, composta por pequenos sítios ou de grandes glebas que, muitas vezes passam a impressão de não oferecerem subsídios, referências e informações de suas tradições, mas o contrário, a paisagem rural brasileira, com seu imenso patrimônio cultural, confere aos estudos patrimoniais uma dimensão socioeconômica importante.

Além da ficha de inventário, desenvolveu-se também para este estudo um aporte teórico acerca dos conceitos de patrimônio material e imaterial, identidade e memória culturais, os quais entende-se que sejam pertinentes ao entendimento do presente texto. Nesse mesmo sentido, será contextualizada a história do município de Santo Antônio do Palma, visto que, ao se tratar da identidade cultural de uma comunidade, é importante explicar sobre a formação desses grupos sociais e a sua relação com o território, de onde vem as características culturais herdadas e de que forma o processo de formação territorial contribuiu para a conformação da paisagem cultural que é tida atualmente.

\section{Compreendendo conceitos}

O patrimônio pode ser compreendido como um conjunto de bens representativos, que pelo seu valor próprio e atribuído pelos grupos sociais que representa, são considerados de interesse relevante para a permanência da identidade e da cultura de uma comunidade. Essa representatividade pode ser classificada em dois grupos: bens materiais e bens imateriais. Conquanto, os bens materiais estão divididos em bens móveis e imóveis. Os bens móveis compreendem a produção pictórica, escultórica, mobiliários e objetos. Os bens imóveis não se restringem ao edificado isolado, mas também ao seu entorno, conjuntura que garante a visibilidade e ambiência do artefato. Estão incluídos neste grupo os núcleos históricos e conjuntos urbanos e paisagísticos. Por bens imateriais entende-se a produção cultural de um povo, desde sua expressão musical até sua memória oral (FIGUEIREDO, 2013). 
De acordo com Canani (2005), o conceito de patrimônio, partindo de definições simples, pode ser compreendido como um conjunto de bens materiais ou, direitos, ações, posses e tudo mais que pertença a uma pessoa. Assim, patrimônio cultural é um bem coletivo que, para ser considerado como um artefato de valor histórico é necessário que possua relevância social, isto é, construído na coletividade.

Para Figueiredo (2013) o patrimônio histórico cultural materializa e torna-se visível segundo um sentimento evocado pela memória cultural e, assim, permite a construção das identidades coletivas, fortalecendo os elos das origens comuns, passo decisivo para a continuidade e a sobrevivência de uma comunidade.

A compreensão de patrimônio cultural possui uma conexão próxima com a ideia de herança, seja de um povo, de uma comunidade ou de uma única pessoa, e é algo a ser deixado ou transferido às futuras gerações. Sobre valores do passado no presente, Gonçalves (2003) sustenta a ideia da antiguidade do tema patrimônio, e que este não é uma invenção da sociedade moderna, mas esteve presente tanto no mundo clássico, como na Idade Média.

Nesse sentido, o patrimônio cultural também pode ser identificado como um instrumento de desenvolvimento local. Esse pensamento é típico da década de 1960, porque estava em suas entrelinhas os fins econômicos de um artefato histórico, como as atividades de turismo e de fortalecimento da noção de pertencimento das comunidades. O patrimônio é a representação material de um território e de uma comunidade, configurando-se em contínua ressignificação (VARINE, 2012). Castriota (2009) defende que o patrimônio cultural deve ser visto como um suporte para o contínuo processo de conformação da vida. Trata-se, portanto, de observar o potencial de transformação que tem o patrimônio, devendo ser periodicamente reavaliado de forma libertária.

Paralelamente à discussão da ideia de patrimônio imaterial, identifica-se diferentes abordagens sobre a dimensão intangível do patrimônio. Muitas dessas abordagens estão associadas ao fato de que se pode entender que a conservação do patrimônio por si só não irá acontecer se não forem incorporados os valores imateriais e intangíveis dos artefatos. Esse argumento é pertinente para o presente artigo porque as discussões acerca do patrimônio centram muito nas proposições de como registrar e conservar, restringindo-se à dimensão física e deixando num plano secundário a imaterialidade dos artefatos.

Sendo assim, torna-se importante contextualizar a visão intangível dos elementos históricos, debates sobre os valores que os patrimônios carregam em si. Para Peixoto (2017) a cultura do imaterial é na sociedade contemporânea a condição fundamental de elevação do artefato material à condição de patrimônio e a promoção de seus usos sociais.

A "Conservação para a Salvaguarda do Patrimônio Imaterial", realizada em 2003 na cidade de Paris, considerou a importância do patrimônio cultural imaterial como fonte de diversidade cultural e garantia de desenvolvimento sustentável, conforme destacado na Recomendação da UNESCO sobre a salvaguarda da cultura tradicional e popular de 1989.

Essa convenção de 2003, definiu como patrimônio cultural imaterial as práticas, representações, expressões, conhecimentos e técnicas diversas, que juntamente dos artefatos e lugares culturais, compõem as comunidades, grupos e indivíduos como parte integrante de seu patrimônio cultural. Esse patrimônio intangível, que é transmitido às gerações, é constantemente reelaborado, expressando ressignificados pelas comunidades e grupos em razão de seu ambiente, de sua interação e continuidade, contribuindo, assim, para a promoção do respeito à diversidade cultural e criatividade humana (UNESCO, 2003). 
Ampliando o conceito, Castriota (2009) defende que o patrimônio imaterial serve como âncora ao próprio patrimônio material, uma vez que se torna uma categoria social quase vazia quando é separado de seus valores culturais imateriais. $O$ autor ainda coloca que essa concepção irá representar uma verdadeira revolução no pensamento sobre o valor do patrimônio.

Tendo a ideia de patrimônio imaterial como um sentimento que está atrelado à memória das pessoas, pode-se, conquanto, associar esse conceito ao conceito de identidade. Segundo Araújo (2007), a identidade de uma sociedade está relacionada a maneira que ela se organiza e territorializa um determinado espaço.

Schneider e Fialho (2015) argumentam sobre o conceito de identidade o fato de poder evoluir a um conceito de identidade coletiva, que se caracteriza como um processo constituído por intermédio da relação entre as dimensões do indivíduo e do seu grupo social. Ambos os autores concordam que a identidade está relacionada a um lugar, a um ambiente físico, e ela é expressivamente social, abrangendo muito mais do que apenas um indivíduo, mas sim um grupo significativo ou até mesmo uma comunidade em geral.

Pode-se considerar que a memória é um elemento importante da identidade. E, memória e identidade, se reforçam mutuamente, contribuindo para a formação das características sociais. Para Santos (2004), a definição da própria identidade cultural envolve em diferenciar os princípios, valores e traçados que a definem, não apenas em relação a ela mesma, mas perante a outras culturas, povos ou sociedades. Memória e identidade são interconectadas, desse entrelaçamento múltiplo abrir-se-á o imaginário histórico cultural de um território.

Na concepção de Batista (2005), a construção da identidade se molda a partir das movimentações de determinado grupo. Esse grupo se apropria de valores e manifestações, perpetuando-os na sua história, passando de geração em geração. Ainda segundo Batista (2005), a identidade local passa a existir congruente à memória, e que essa nada mais é do que uma resistência de grupos que não querem esquecer suas características e tradições, muito pelo contrário, querem preservá-la e perpetuá-la para as futuras gerações. Pollak (1992) complementa afirmando que memória é o elemento que constitui o sentimento de identidade individual e coletiva, na medida em que ela é fator extremamente importante para o sentimento de continuidade de um grupo.

Nessa perspectiva, concordamos com Santos (2004) ao afirmar que a ligação entre memória e identidade é tão profunda que o imaginário histórico-cultural se alimenta delas para se autossustentar e se reconhecer como expressão particular de um determinado povo. Sendo assim, o propósito deste estudo vem ao encontro daquilo que as concepções dos autores abordados justificam, sendo o processo de inventariamento do saber-fazer local uma forma, antes de mais nada, de reconhecer a identidade e a memória de uma comunidade, assim como salvaguardar o seu conhecimento popular.

Entende-se que as sociedades não constroem ao longo do tempo teorias a respeito de suas próprias práticas e nem se referem aos seus hábitos do cotidiano como algo de valor patrimonial. Para esses grupos sociais, o conhecimento, o saber-fazer, as formas de expressão, rituais, crenças e o folclore, por exemplo, são meras características e hábitos enraizados em seu cotidiano.

É importante ressaltar que as comunidades se transformam culturalmente, assim como alteram as formas de transmissão dessa cultura, aqui denominada de imaterial, conquanto ela é adequada a dimensão contemporânea, conforme novas necessidades. Sendo assim, temos como pressuposto, que cabe aos especialistas e as instituições culturais o reconhecimento das culturas populares, através de abordagens holísticas entre os detentores desse conhecimento e visões sistêmicas e processuais, gerando levantamentos que elucidem os vínculos simbólicos e práticos do saber-fazer, reconhecendo 
e fomentando a consolidação das mais diversas identidades, contribuindo para a conservação das tradições culturais.

\section{A caracterização do território: o município de Santo Antônio do Palma/RS}

Entende-se que para a compreensão de uma conjuntura social e cultural ativa nos dias atuais é necessário olhar para o passado, lendo através dos fatos históricos, quais marcas desses processos foram importantes para a construção dos aspectos culturais contemporâneos.

Segundo Meneses (2006), para compreender a cidade como um bem cultural é preciso compreendê-la quanto seus aspectos relacionados ao universo dos sentidos, das percepções e dos valores de memória, identidades, ideologias, expectativas etc. Nesse sentido, sob esse viés, é elaborado um breve aporte temporal acerca da formação do município de Santo Antônio do Palma, desde a chegada dos primeiros imigrantes até os dias atuais. Geograficamente esse município de aproximadamente 2.300 habitantes (IBGE 2010), considerado de pequeno porte, está localizado ao norte do estado do Rio Grande do Sul, Brasil (Figura 01).

Figura 1: Esquema de localização do município de Santo Antônio do Palma, Rio Grande do Sul, Brasil.

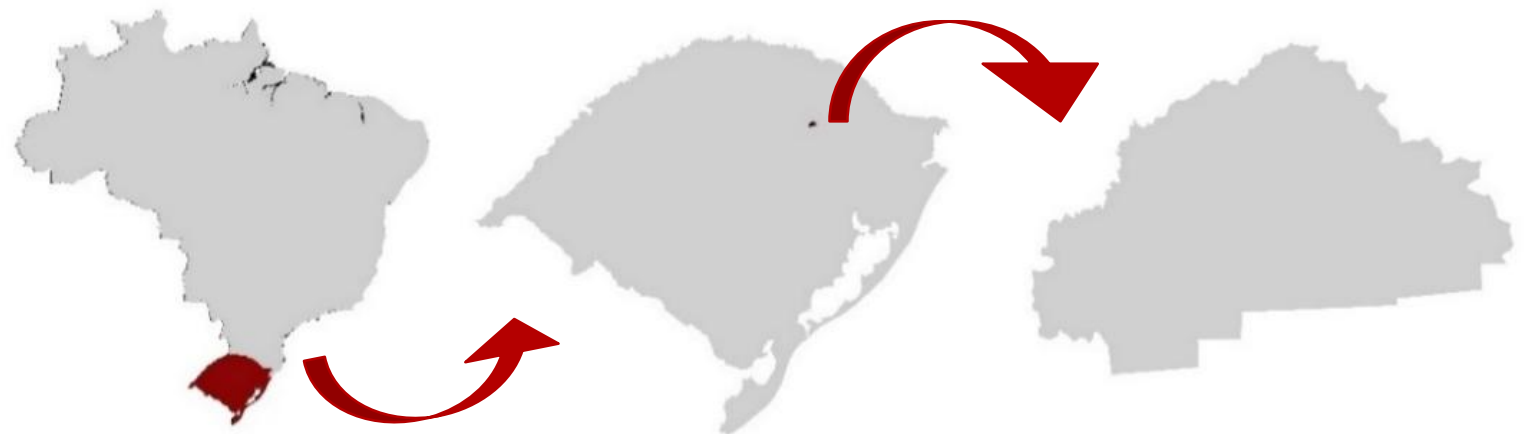

Fonte: Autores (2020).

O território que hoje compreende o município de Santo Antônio do Palma teve seus primeiros movimentos migratórios datados entre os anos de 1904 e 1906 (GELATTI, 1985). Foi entre nesse período que iniciou a formação das primeiras comunidades de descendentes de imigrantes italianos, vindos de antigas colônias, como a de Alfredo Chaves (atual município de Veranópolis/RS), e da própria colônia de Guaporé (atualmente município com esse mesmo nome), a qual o território fazia parte na época (Figura 2).

Figura 2 - Mapa das colônias de imigrantes europeus ao norte do Rio Grande do Sul, Brasil.

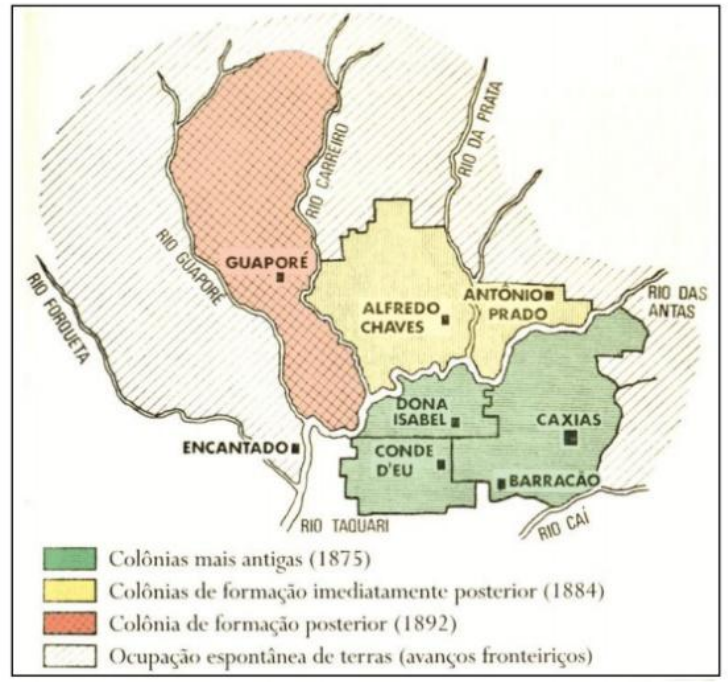

Fonte: Frozi e Mioranza (1975) 
Segundo Gelatti (1985), as famílias que chegaram a esse território o ocuparam dividindo-o em forma de pequenas comunidades, que se caracterizavam por serem de totalidade de descendentes de imigrantes italianos, ou então, mais tardiamente, de poloneses. O idioma foi um dos principais fatores que contribuiu para a formação deste estilo de agrupamento. Quanto a formação das comunidades de imigrantes, "os grupos culturalmente homogêneos foi uma reação espontânea dos imigrantes europeus face ao isolamento e ao abandono de que foram vítimas nos primeiros tempos de colonização" (MANFRÓI, 1975, p. 247). Nesse contexto, consideramos que esse fator tenha contribuído para a conservação do patrimônio cultural e da identidade dessas comunidades, assim como incentivou a solidariedade étnica entre os imigrantes.

Uma das comunidades de imigrantes, em sua maioria italianos, estabeleceu-se junto à rota dos tropeiros e carreteiros (Figura 3). Segundo Tedesco e Balbinot (2014), essa rota que ligava os municípios de Muçum até Passo Fundo, via Campo do Meio, era conhecida como Estrada Tiradentes, a qual cruzava a maior parte das colônias de imigrantes e era responsável por abastecer o comércio local com produtos que chegavam pelo porto de Muçum e que tinham como destino o comércio consolidado da cidade de Passo Fundo.

Figura 3 - Carreteiros que faziam o trajeto Muçum - Passo Fundo abastecendo o comércio local.

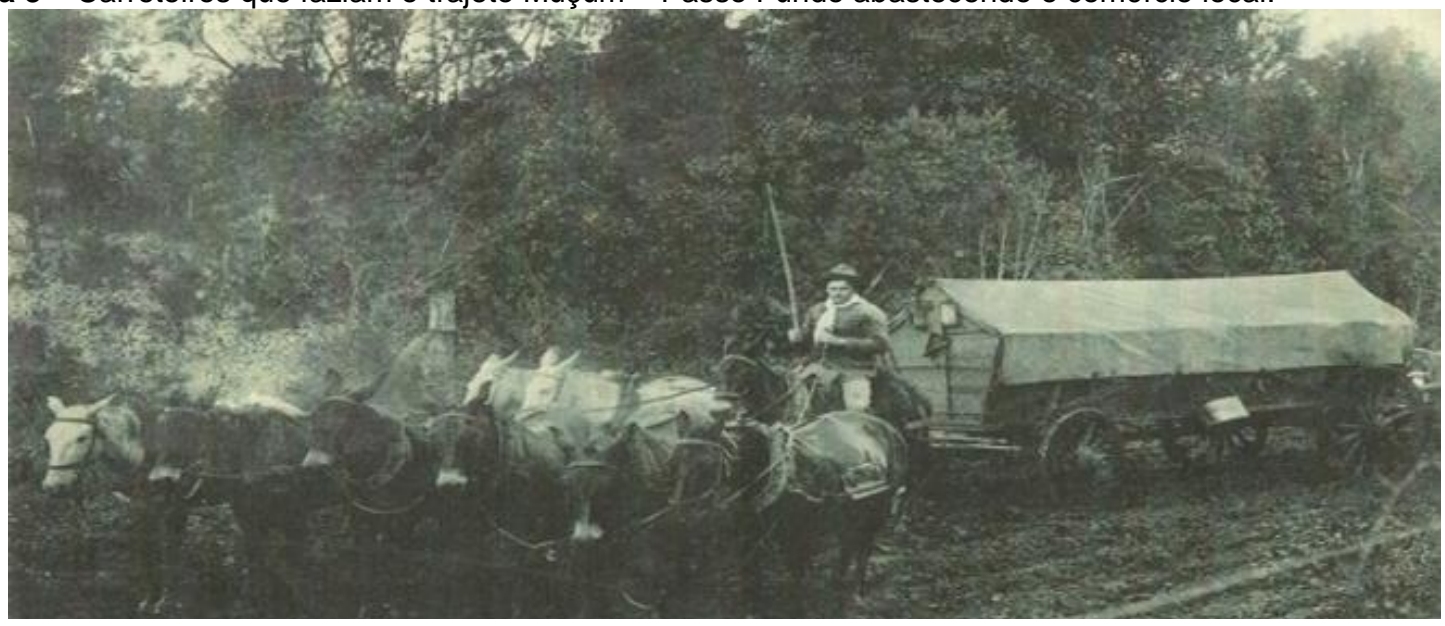

Fonte: Tedesco; Balbinot (2014).

Foi esta comunidade, instalada junto à rota dos tropeiros, que no decorrer dos anos e sob influência do comércio, passou a ser a mais estruturada e com a maior população. Daquele pequeno aglomerado de famílias e a partir de sua consolidação como área comercial veio a se tornar a zona urbana do município.

Um pouco mais tarde, em meados de 1910, iniciou a formação das primeiras comunidades de imigrantes poloneses na região, onde atualmente é Santo Antônio do Palma/RS. De acordo com Gelatti (1985), essas famílias fixaram-se em áreas montanhosas, difíceis de serem trabalhadas e devido à semelhança com o relevo da cadeia de montanhas de Cárpatos, na Polônia, denominaram suas novas colônias, em solo brasileiro, de Montes Cárpatos, como uma forma de homenagem, e sacralizaram este local em devoção à Nossa Senhora de Czenstochowa, uma conhecida santa católica polonesa.

Conforme o mapa a seguir, é possível notar a distribuição das primeiras comunidades de imigrantes que chegaram ao território do município supracitado. Nele, destacam-se através de uma linha tracejada verde a rota dos carreteiros e tropeiros, um dos principais movimentos que contribuiu para o desenvolvimento local. A linha verde pontilhada representa as entradas vicinais que foram abertas pelos imigrantes ao chegarem nestas paragens, tornando possível o acesso às colônias. Quanto a linha pon- 
tilhada azul, ela representa as estradas que foram abertas posteriormente, ligando Santo Antônio do Palma aos municípios vizinhos (Figura 4).

Figura 4 - Atual mapa do Município de Santo Antônio do Palma, com a marcação das primeiras comunidades de imigrantes formadas.

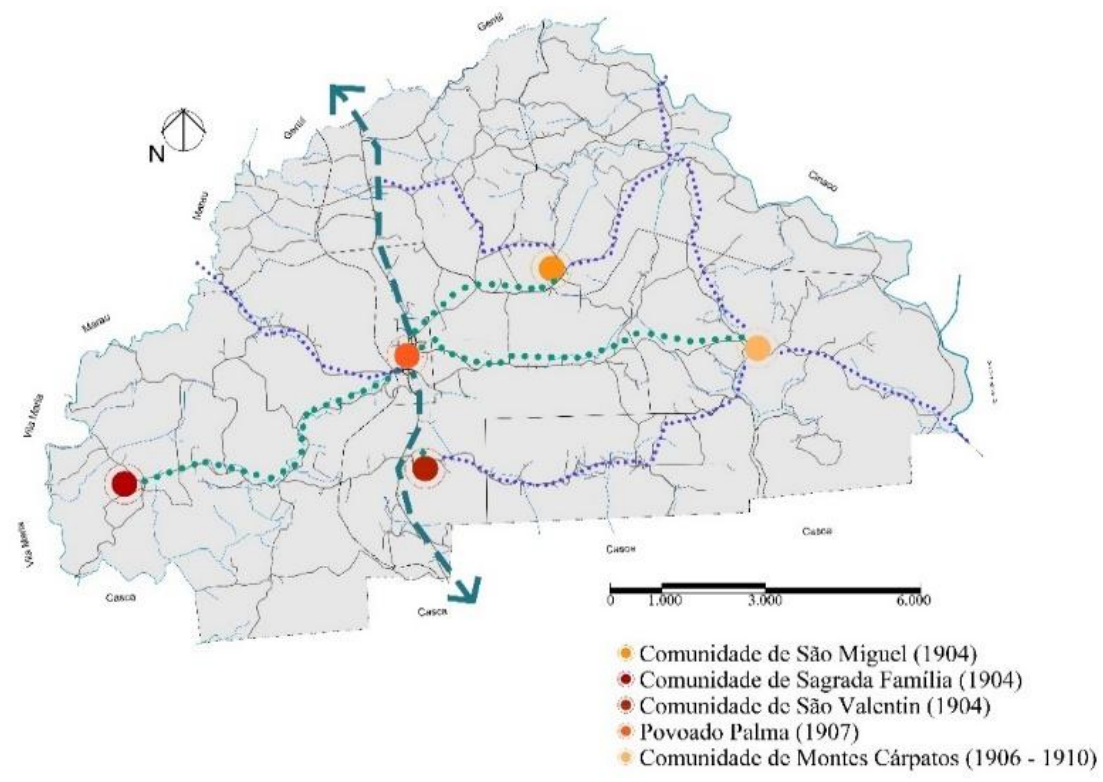

Fonte: Desenvolvido pelos autores com base em mapas municipais e estaduais (2020).

No tocante as questões administrativas e políticas, ao longo dos anos, o então município passou por alguns avanços. Dentre eles, o primeiro que se pode destacar foi seu reconhecimento como um distrito. Segundo Roque Gelatti (1985), foi através da Lei no 190, de 12 de dezembro de 1926, que o então prefeito do município de Casca/RS à época, Sr. Arcido Perin, em acordo com as leis orgânicas do município decretou a criação do $4^{\circ}$ Distrito, sendo esse o de Santo Antônio, também conhecido como Linha Gonçalves Dias, Povoado Palma ou Povoado Chiodelli.

Após alguns anos sob a denominação de distrito do então município de Casca/RS, em meados de 1990, a comunidade local, com base na sua independência, principalmente, financeira e comercial, passou a movimentar-se em prol da emancipação política administrativa (Figura 5). De acordo com os registros históricos do processo de emancipação, a comissão emancipacionista realizou uma intensa busca por documentos que comprovassem ao governo do estado do Rio Grande do Sul sua autonomia. Sendo assim, o então distrito de Santo Antônio foi elevado à categoria de município com a denominação de Santo Antônio do Palma, pela Lei Estadual n‥ 9.591, de 20/03/1992, desmembrado do município de Casca/RS. 
Figura 5 - Cartaz da campanha Pró-Emancipação

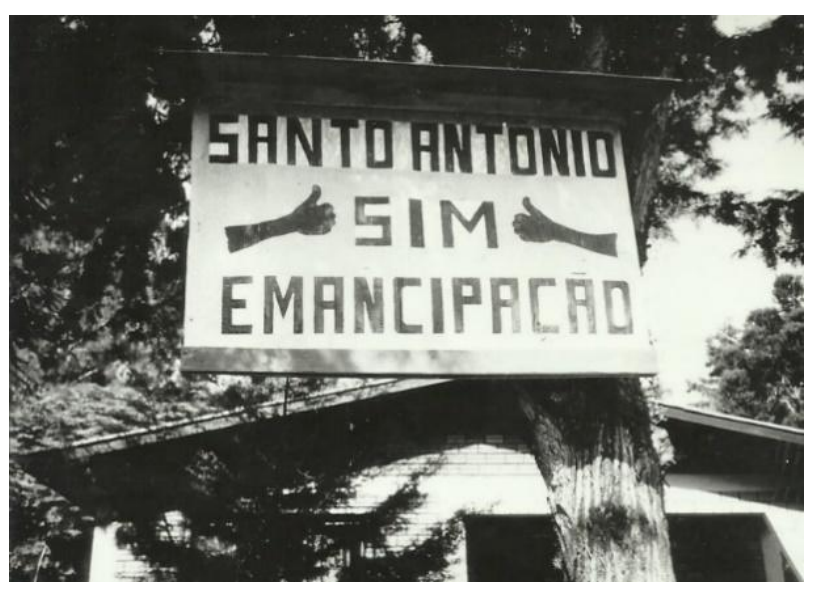

Fonte: Arquivo Histórico de Santo Antônio do Palma (1992).

De acordo com informações da Prefeitura Municipal (2017), atualmente o município se destaca pela sua produção agroecológica, o que podemos identificar como uma herança dos imigrantes, os quais dedicaram seus esforços nas culturas agrícolas. Além desse aspecto, conserva em seu dia a dia costumes e valores de tradições culturais que foram transmitidas entre gerações, o que auxilia na conservação da identidade local.

Nesse ensejo, concordamos com Meneses (2006) ao citar que a cidade é um artefato socialmente produzido, onde as práticas, formas e funções lhe dão sentido. Sob essa perspectiva, o autor argumenta que a cidade é uma representação, uma imagem que reflete seus autores, ou seja, os atores locais que colocam na cidade respectivos fragmentos particulares de suas culturas.

Ainda segundo Meneses (2006), pode-se compreender a cidade ou município como um bem cultural como aquela marcada por sentidos e valores, instituídos nas práticas sociais e necessários para que elas revistam da marca específica da condição humana. Assim, a cidade culturalmente qualificada é boa para ser conhecida, boa para ser contemplada, esteticamente fruída, analisada, apropriada pela memória, consumida afetiva e identitariamente, mas também, e acima de tudo, é boa para ser praticada na plenitude de seu potencial.

\section{Inventariar para salvaguardar}

Sendo o propósito principal do presente texto reconhecer e inventariar o patrimônio material, imaterial e o saber-fazer das comunidades rurais de Santo Antônio do Palma/RS, esse tópico discorrer-se-á acerca dos resultados obtidos durante a pesquisa de campo, onde foram identificados os artefatos culturais adotados como objetos de estudo para o trabalho em tela.

Azevedo (1998) argumenta que para além de sua função primária de identificação, o inventário contribui positivamente para o processo de conscientização acerca do patrimônio cultural. Nessa perspectiva, além do patrimônio construído, em sua elaboração, a ficha de inventário proposta contemplou a dimensão do patrimônio imaterial e do saber fazer, estimulado pela razão de que esse conjunto de bens patrimoniais pertence a um grupo ou uma comunidade, que através de seus esforços pessoais busca sua ressignificação cultural. Para Gonçalves (2003) os grupos sociais ou indivíduos em sua singularidade buscam, através da memorização e colecionamento de objetos e sítios, preservar artefatos e práticas que referem e reafirmam sua identidade cultural, guardando em si relevância social.

Tendo como base o entendimento dos autores até aqui utilizados como referências conceituais e teóricas, foram selecionados dois artefatos culturais para serem inventariados. Esses bens patrimoniais, propriamente ditos, referem a duas propriedades fundiárias localizadas na zona rural do município de 
Santo Antônio do Palma/RS, onde cada uma delas possui aspectos culturais relevantes, sendo uma expressando características preservadas da imigração italiana e outra da imigração polonesa.

A justificativa da escolha desses bens se deu pelo fato de que ambos mantêm em seu cotidiano traços e características que foram transmitidas entre as gerações, ou seja, aspectos imateriais como o saberfazer e elementos preservados da paisagem local, como os antigos casarões, herança do período de colonização do município em análise. Por tais motivos e também pela atuação dos atores locais na busca pela preservação de suas respectivas memórias, assim como o patrimônio construído, as duas propriedades recebem visitantes, turistas, grupos escolares e pesquisadores que despertaram interesse em vivenciar a história e a memória que esses locais ainda preservam.

\subsection{Heranças da imigração italiana}

O primeiro artefato cultural inventariado é uma propriedade familiar rural que preserva as memórias, a identidade, o saber-fazer e o patrimônio construído que foi transmitido entre as cinco gerações da família de imigrantes italianos. Foram inventariados o casarão da família e o saber-fazer do lenho, ou seja, os trabalhos de carpintaria.

Singular na paisagem, o casarão vernacular da família foi construído em 1924 pelo seu proprietário, logo que chegou nessas terras. A casa possui traços típicos das construções vernaculares da época da imigração no Rio Grande do Sul. É formada por três pavimentos e tem como materiais construtivos a pedra e a madeira, abundantes na época (Figura 6). Para Lemos (1996), vernacular é a arquitetura feita pelo povo, ou por uma sociedade qualquer, com seu limitado repertório de conhecimentos e num ambiente definido que fornece determinados materiais ou recursos.

Figura 6 - Casarão inventariado. Nesta imagem podem ser identificados os materiais construtivos, bem como as divisões de pavimentos: porão, térreo e sótão.

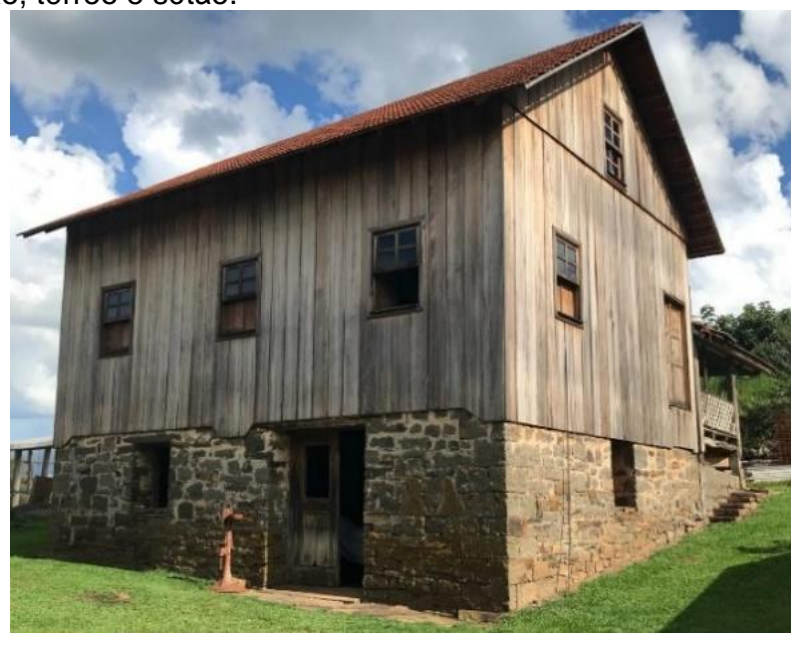

Fonte: Autores (2020)

A casa foi implantada em uma encosta, onde parte do porão fica parcialmente escavado. Essa organização construtiva era fundamental para que o local mantivesse sua temperatura constante, pois era no porão que se armazenava parte da produção da família, principalmente o vinho e carnes. Além de espaço de armazenamento, em diversos casos, assim como neste que está sendo explicado, o porão também funcionava como uma oficina, onde realizavam-se inúmeras tarefas, desde pequenos consertos até a produção de objetos para comercialização. $O$ andar principal da casa possui pé direito alto $e$ inicialmente era dividido em dois blocos, sendo um deles destinado apenas à cozinha e o outro para a sala e dormitórios, onde eram interligados por uma passarela.

A principal motivação de construir a casa em blocos distintos estava relacionada com a prevenção contra possíveis incêndios, visto que na cozinha, inicialmente, utilizava-se um fogo de chão e a mesma era edificada toda em madeira, altamente inflamável. Alguns anos após a casa construída e com o 
avanço dos fogões, especialmente o fogão a lenha, muitas famílias optaram por unir a cozinha com o bloco dos dormitórios e sala. Para auxiliar na compreensão do processo de modernização dessa construção, foi desenvolvida uma modelagem 3D de como a casa era inicialmente, baseando-se nas memórias dos moradores, onde é possível estabelecer uma comparação com a atual situação (Figuras 7 e 8).

Figura 7 - Simulação 3D de como a casa foi edificada inicialmente.

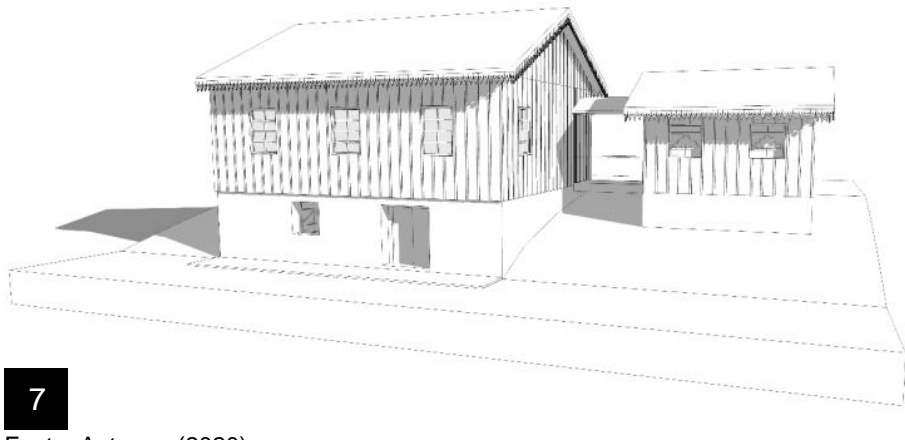

Figura 8 - Atual situação da casa, após as intervenções de layout.

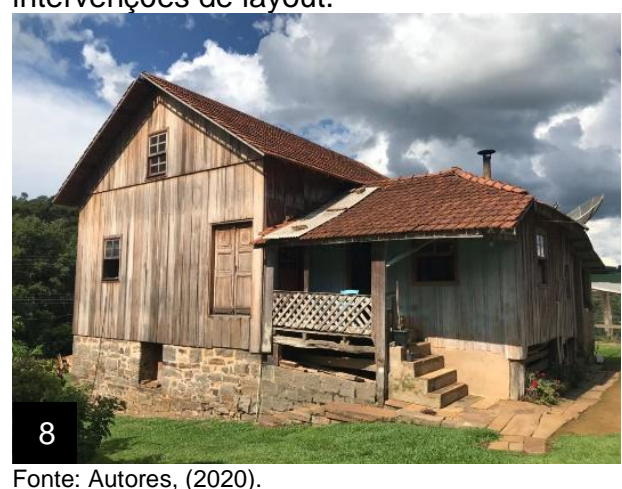

Além dessa, outras reformas foram realizadas na residência, entre elas, destaca-se a substituição do telhado original de tabuinhas, ou "scandolé", que era executado em madeira lascada no local, com medidas irregulares pela telha colonial cerâmica. Nessa modificação a família optou pela retirada dos lambrequins que ornamentavam os beirais, visto que muitos já haviam caído ou apresentavam patologias, assim como, haviam motivações para se modernizar a casa por parte dos proprietários.

Após 95 anos de sua construção, a residência apresentava uma série de patologias, como rachaduras e apodrecimento das extremidades das tábuas que vedam a casa, infiltração no telhado, em função da sua estrutura estar comprometida, bem como o desprendimento das ripas, chamadas de "mata junta" que cobrem as emendas das tábuas, evitando as frestas. Por tais razões, em meados de 2019 a família optou por um processo de conservação e restauro da casa, buscando valorizar a história da propriedade e a memória dos antepassados da família. O processo de restauro e conservação da residência vem sendo feito pelos próprios moradores, que aos poucos executam os reparos necessários.

Esse movimento dos atores locais se consolida como um importante instrumento que contribui para a reafirmação de suas identidades, memórias e de suas tradições culturais. Através do inventariamento do saber-fazer nota-se que o saber de cada um dos ofícios presentes no cotidiano da família está sendo transmitido em seus diversos aspectos, desde o simples modo de fazer, até os conhecimentos que existem em cada uma das etapas. A transição intergeracional dos ofícios dessa família de imigrantes italianos permite que hoje, três gerações passadas, a casa possa ser restaurada mantendo não somente seu aspecto material, mas também sua essência, seus significados e originalidade (Figura 9). 
Figura 9 - A confecção de um lambrequim que será recolocado na residência da família.

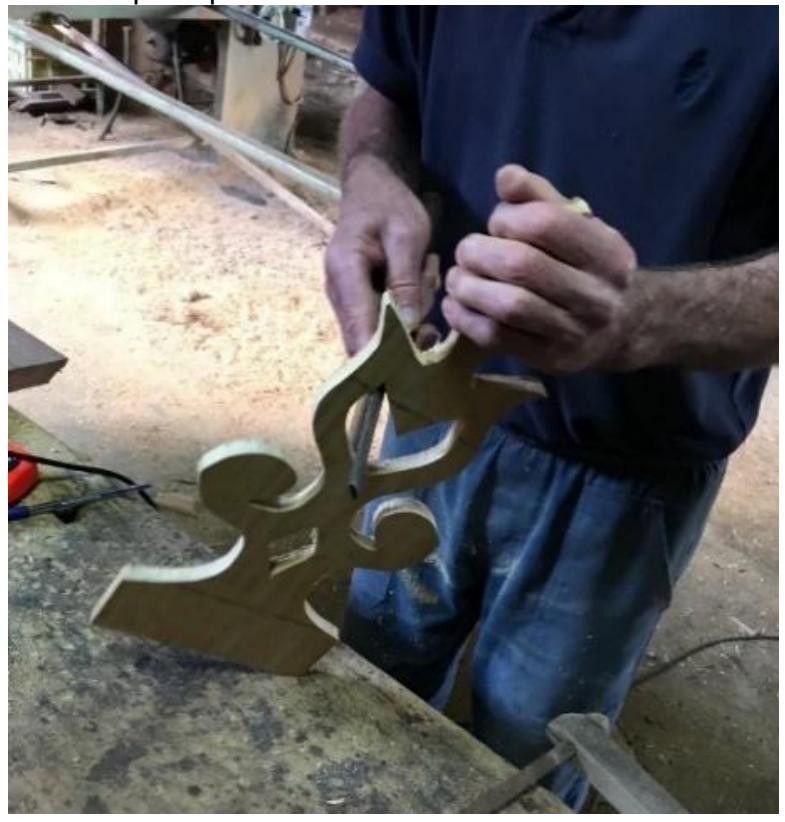

Fonte: Autores (2020).

Para além dos aspectos materiais, uma construção vernácula preserva em si uma série de saberes, com os quais foi possível edifica-la. Esses saberes estão associados ao ofício da carpintaria, fortemente presente nas famílias de imigrantes. Construir uma casa, por mais simples e rústica que ela fosse, demandava algumas etapas, tais como: a extração da matéria prima bruta nas abundantes matas de araucárias, o beneficiamento desse material e o emprego dele, a começar pelos elementos estruturais, vedação, primorosos acabamentos e a confecção do mobiliário interno.

Um dos fatores, destacado por um dos membros dessa família italiana, no âmbito comunitário e regional, é o domínio sobre os saberes que envolvia a madeira. A partir da bagagem cultural o imigrante e artesão constitui-se como uma referência na construção de casas em madeira, particularmente, quanto ao primoroso trabalho e dedicação na produção de lambrequins para as casas da região, a marcenaria e a fabricação de barris de vinho (Figura 10).

Figura 10 - Lambrequins produzidos pelo Sr. Â.S. para uma residência de imigrantes italianos na zona rural do município de Casca/RS.

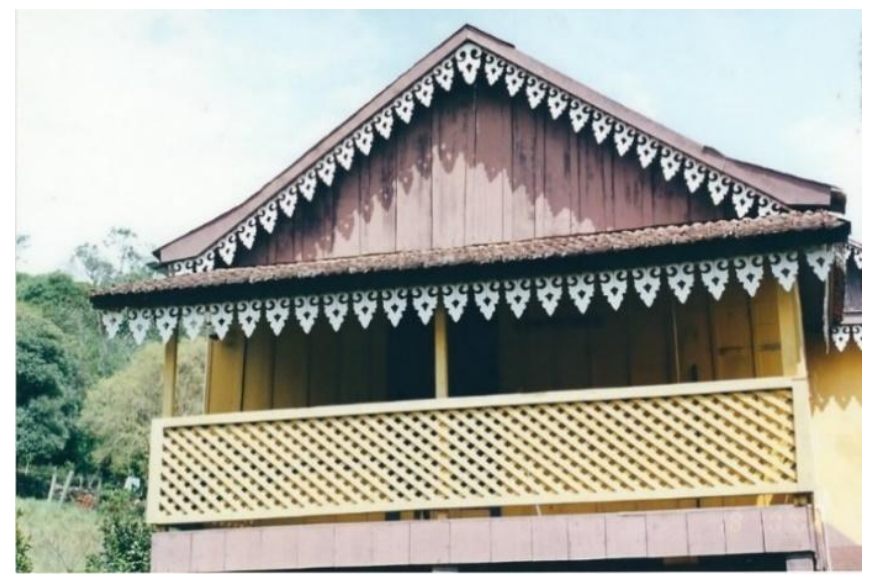

Fonte: Museu Municipal Albino Busato (s/d).

A prática deste ofício não se resumiu apenas ao patriarca da família. O saber-fazer da carpintaria e marcenaria foi transmitindo entre as quatro gerações dos membros, e sempre teve um papel de destaque, principalmente econômico. Consequentemente, com o passar dos anos e com os avanços tecno- 
lógicos e comerciais, esse ofício pode ser ainda mais aprimorado, onde, novos equipamentos podem ser incorporados ao dia a dia da pequena marcenaria (Figura 11).

Figura 11 - Marcenaria da família italiana. Entre os equipamentos e maquinas modernas é possível notar a primeira bancada de trabalho que era utilizada pelo patriarca da família, no canto à esquerda.

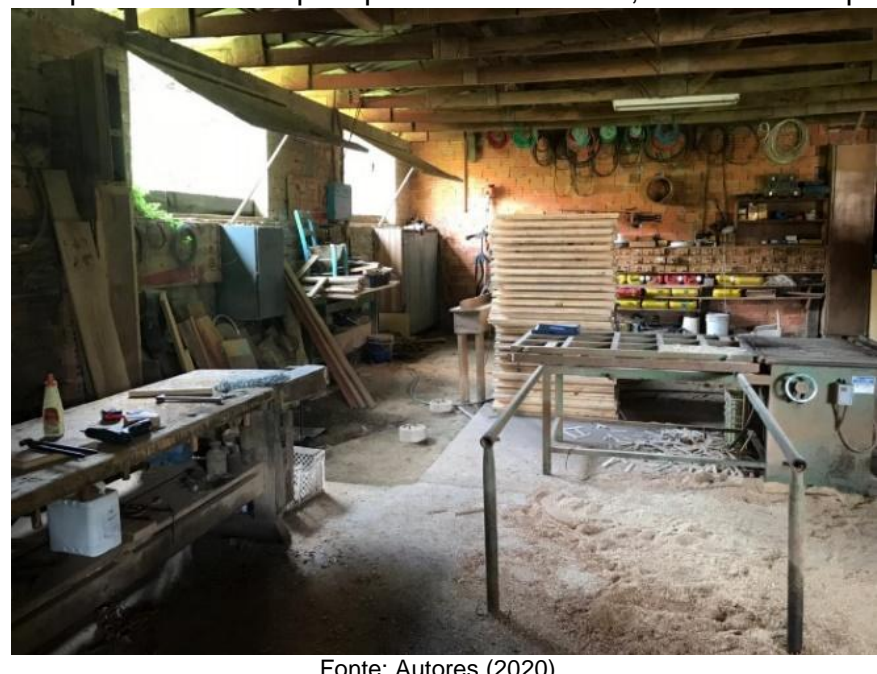

A transmissão de conhecimento entre as gerações é um aspecto que contribui para a manutenção da identidade cultural das comunidades, seja essa identidade, comercial, industrial, natural, gastronômica, entre outras que compõem a paisagem cultural das colônias de imigrantes europeus no Rio Grande do Sul. Assim, como o caso do saber-fazer inventariado relacionado a madeira, contextualiza-se esse olhar às outras atividades, que ao longo do tempo se transformaram de um ofício para atender as demandas familiares, à estruturação de pequenas indústrias, contribuindo no desenvolvimento das comunidades locais.

Merecem atenção nos casos de preservação de referências culturais coletivas, conferir destaque em como as questões identitárias, em uma perspectiva individual e coletiva, são identificadas no sentido do reconhecimento daquele bem como pertencente à categoria de patrimônio, estabelecendo conexões com contextos passados, assim como interesses sociais e políticos que permeiam seu processo de preservação.

\subsection{Heranças da imigração polonesa}

Semelhante ao primeiro caso, o artefato cultural a ser apresentado neste subtópico também é uma propriedade rural no município de Santo Antônio do Palma, contudo, essa possui traços culturais e origens polonesas. A propriedade da família polonesa está implantada em uma comunidade formada, majoritariamente, por descendentes de imigrantes poloneses. A justificativa para a abordagem desse conjunto no presente artigo se fundamenta nos aspectos materiais e imateriais presentes nesse sítio.

Quanto ao aspecto material, a residência da família se destaca na paisagem local pelos seus aspectos folclóricos. A manutenção deste bem arquitetônico contribui para a conservação das características locais e o senso de pertencimento e identidade da comunidade polonesa. A construção de 1967, que mantém até hoje marcas culturais originais é um marco na paisagem local, uma vez que nela foram aplicados símbolos do folclore polonês (Figura 12). 
Figura 12 - Residência da família polonesa. Nela pode-se observar uma série de pinturas e arabescos tradicionais do folclore polonês.

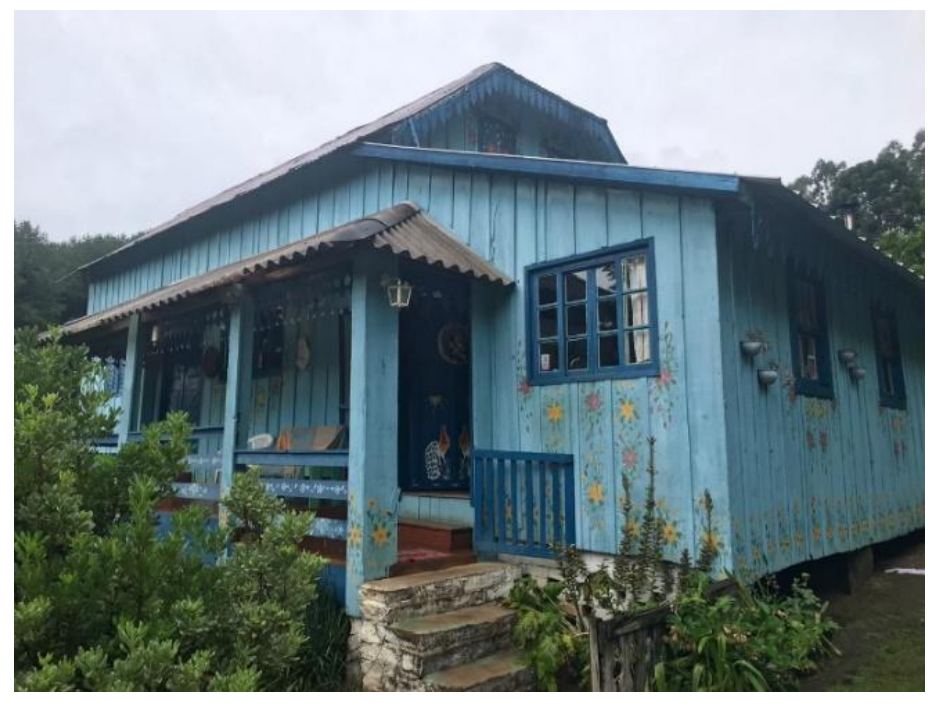

Fonte: Autores (2020).

Essa residência também possui características vernaculares, tendo a madeira como principal elemento construtivo, sendo empregada no andar principal e sótão. No porão destaca-se o uso de pedras e tijolos maciços. No térreo está localizada a cozinha, por onde se dá o acesso principal da casa. Esse espaço possui um papel importante para o convívio familiar, pois é onde a família se reúne para as diversas refeições, assim como para momentos de convívio e lazer.

O porão, edificado em pedras e blocos cerâmicos maciços, é utilizado como depósito e oficina da família. Nele armazena-se parte da produção, bem como é onde são realizados pequenos consertos e reparos no cotidiano familiar. Segundo Filippon (2007), essa casa seria um exemplo típico de construção de um período muito expressivo das tradições culturais polonesas na região, onde a casa, grande e ampla, não se constituía apenas em uma mera moradia, mas também como local de trabalho, representando a ascensão social do seu proprietário.

A pintura é a principal característica desta construção e o que a diferencia e a destaca na paisagem. A tradição de decorar a casa com os símbolos poloneses está presente em todas as gerações dessa família. Consequentemente, com o tempo, a técnica foi aprimorada, cores e tintas de maior durabilidade passaram a ser utilizadas (Figura 13). Segundo a proprietária da residência, que é a responsável pela pintura, na casa de sua avó, assim como de sua mãe, as gravuras eram feitas principalmente nas portas e janelas com o uso da cal $(\mathrm{CaO})$ diluída em água.

Segundo a artesã, sua inspiração para realizar esse tipo de gravura vem das memórias de infância, época em que ela e sua irmã visitavam a casa da avó materna, onde viam os galos pintados. Os galos poloneses são as figuras mais utilizadas nessa manifestação artística, pois eles representam a bravura do povo polonês, assim como atraem conquistas e fertilidade. Conforme Maradei (2017), a tradição de pintar as casas surgiu na Vila de Zalipie, na Polônia, na tentativa de disfarçar e encobrir as marcas da fuligem causadas pelas chaminés (Figura 14). 
Figura 13 - A descente polonesa dando manutenção na pintura da casa.

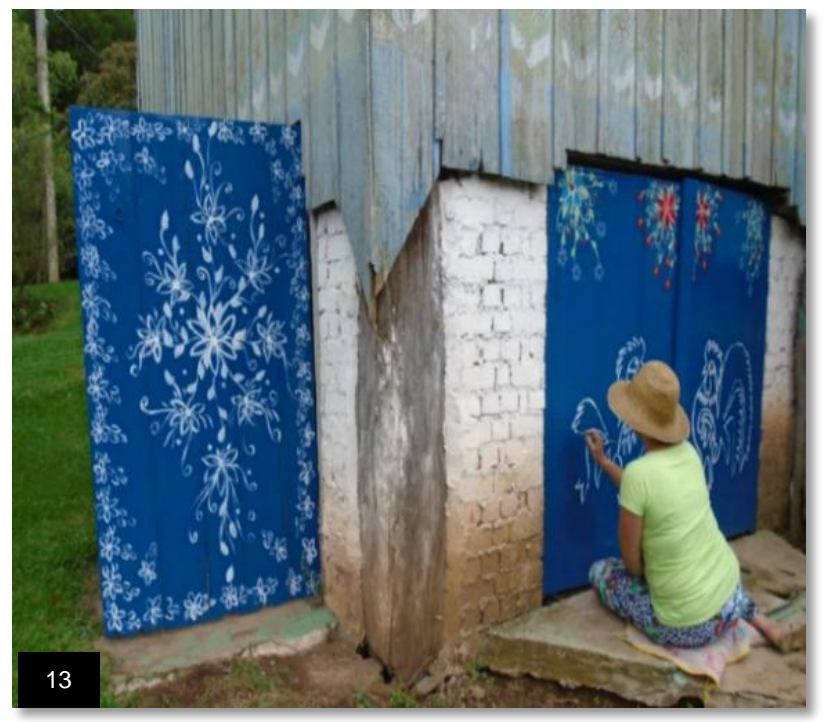

Fonte: Família polonesa (2002).
Figura 14 - Porta de entrada da casa da família.

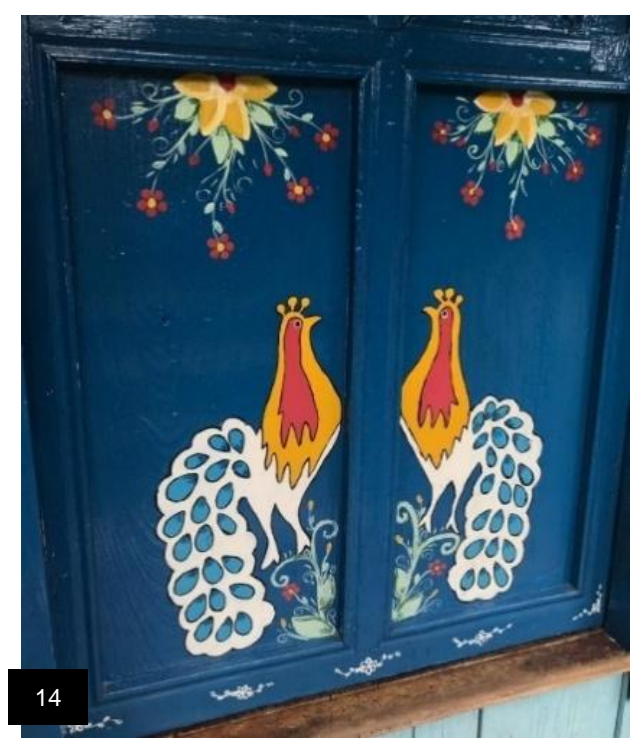

Fonte: Família polonesa (2002)

Além da construção vernacular que exibe traços do folclore polonês, na propriedade também é possível observar o saber-fazer no artesanato típico polonês, conhecido como Lepianka, tradicional arte originária da região da Krakôvia que consiste em uma espécie de marchetaria que utiliza a colagem de palha de trigo ou aveia para formar desenhos, mosaicos ou figuras que possuem simbologias, como fertilidade, prosperidade, saúde, fartura, sorte, entre outras boas aspirações relacionadas às cores ou símbolos da natureza, como as flores, árvores e trigo, os quais representam a prosperidade, caridade, felicidade e beleza (RINDOS, 2012) (Figura 15).

Figura 15 - Esse objeto foi um presente que a moradora recebeu de uma artesã polonesa da cidade de Curitiba/PR. Essa peça foi a sua inspiração para que iniciasse trabalhos artesanais como uma atividade comercial.

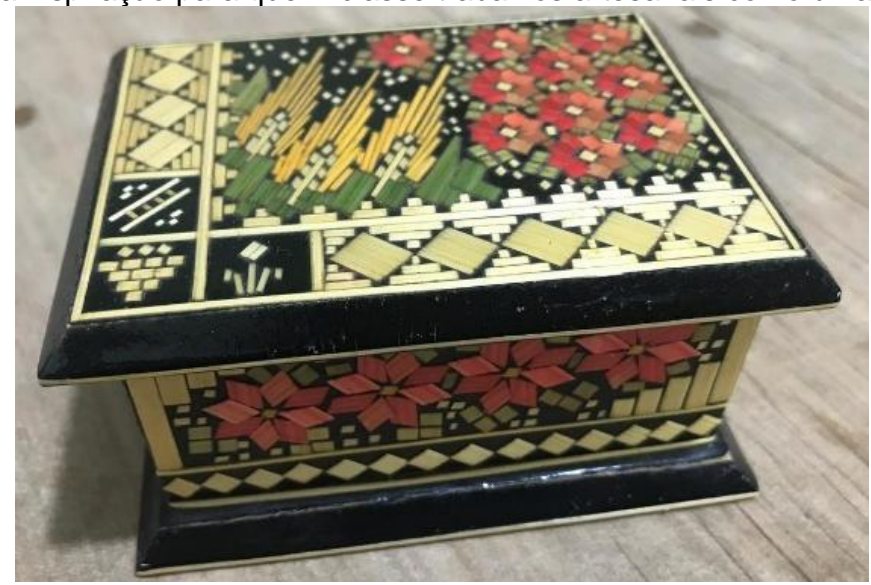

Fonte: Autores (2020).

Da mesma forma que a tradição de pintar suas casas, o artesanato típico foi transmitido para a artesã pela sua avó, uma imigrante polonesa que veio para o Brasil em meados de 1890. A artesã relembra que quando criança, seu avô deslocava-se para a cidade de Casca/RS, onde fazia as compras do mês, e quando de volta, sua avó guardava os papeis que embrulhavam as mercadorias para que as netas pudessem utilizá-lo como uma tela para colarem pedaços coloridos de papeis de balas, formando, assim, as primeiras gravuras. 
Para a artesã, manter vivo o saber-fazer da lepianka é uma forma de revisitar sua memória e de seus antepassados, os quais, segundo ela, prezavam muito para que as tradições polonesas fossem mantidas, mesmo distantes de seu país de origem. Em sua infância o artesanato era feito como atividade lúdica, posteriormente, passou a fazer alguns trabalhos específicos e nos últimos doze anos essa técnica passou a ser a principal fonte de renda da família. A maior parte das etapas desse trabalho é feita na própria propriedade, o que pode levar meses, uma vez que a artesã opta por semear e cultivar o trigo que irá utilizar no artesanato (Figura 16). Sendo assim, a semeadura do trigo é a primeira de uma série de etapas necessárias. Após semeado, o trigo necessita de cuidados específicos para que tenha qualidade e produza uma palha rígida, a qual será colhida e secada ao sol (Figuras 17 e 18).

Figura 16 - Semeadura do trigo, realizada no inverno; Figura 17 - Colheita do trigo; Figura 18 - Secagem das palhas de trigo ao sol.
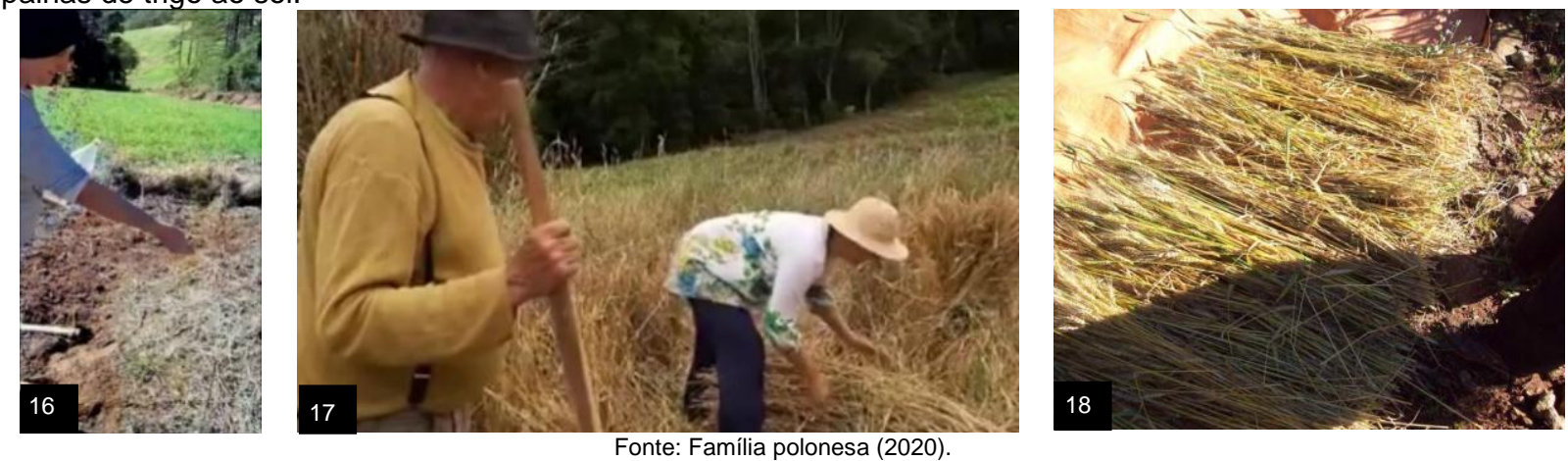

Após a palha estar completamente seca, parte dela passa pelo processo de pigmentação (Figura 19). Para tanto, as palhas são fervidas em água com corante durante o tempo aproximado de cinco minutos. Após tingidas, passam pelo processo de alisamento, onde são abertas e alisadas com ferro de passar (Figura 20). Após essas etapas a palha está pronta para ser utilizada no artesanato, a partir daqui se inicia a confecção dos produtos. A palha é cortada, conforme o formato que se deseja, e sobreposta sob a superfície que receberá a técnica de colagem (Figura 21).

Figura 19 - Tingimento das palhas de trigo; Figura 20 - Alisamento das palhas; Figura 21 - Processo de colagem.
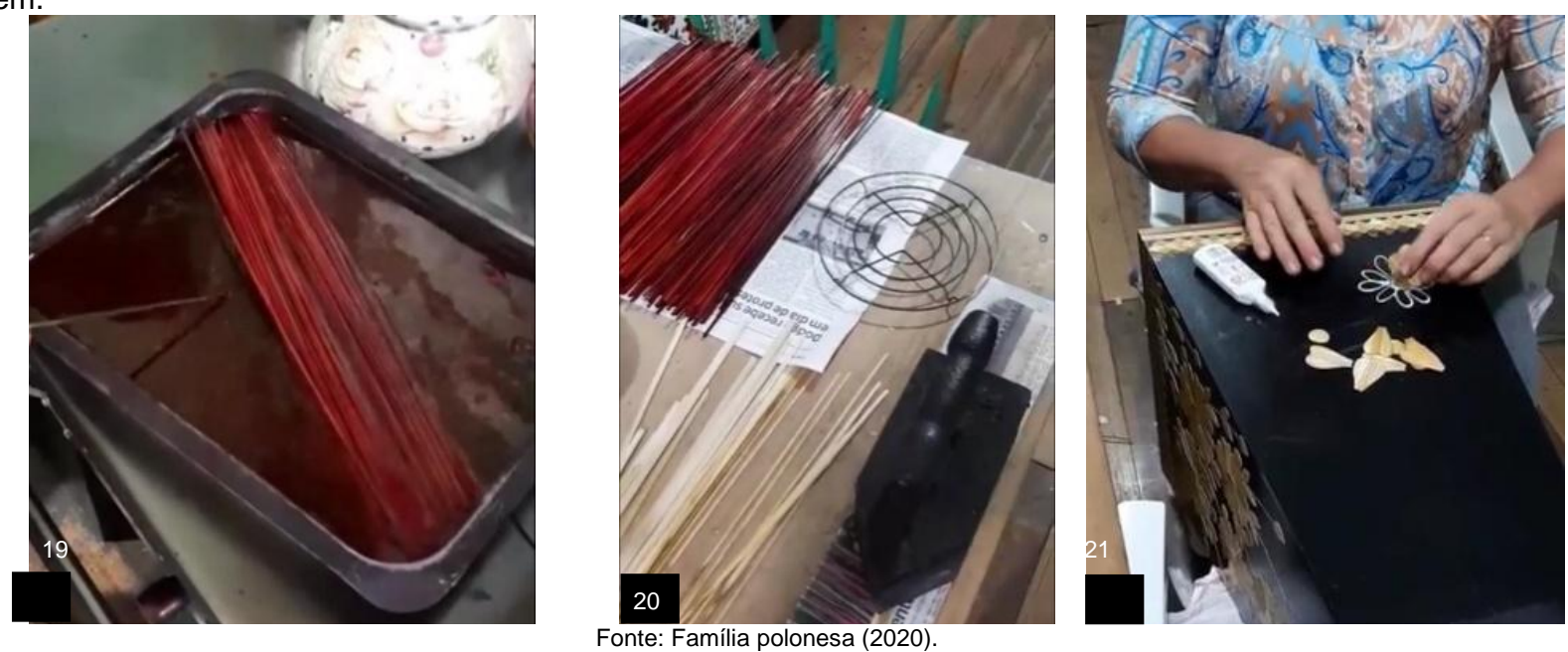

Assim que a colagem é finalizada, novamente volta-se a usar o ferro de passar, dessa vez, sob o artesanato finalizado. Isso é feito para que a colagem fique lisa e nivelada. Por fim, são dadas três demãos de verniz, garantindo que o produto tenha maior durabilidade. Em grande parte, esses produtos são comercializados em feiras locais e regionais, contudo, especialmente durante os anos de 2020 e 2021 , em função da pandemia do Covid-19, a venda vem acontecendo on-line. 
Uma das questões inerentes a presente pesquisa é quanto à forma de manutenção e transmissão do conhecimento. A artesão relata que elas acontecem de duas maneiras. A primeira delas num processo gradual, transmitindo seu saber para sua filha primogênita. Quanto a segunda maneira, a artesã compartilha seu conhecimento promovendo oficinas e workshops. Esses normalmente são desenvolvidas em instituições como universidades, escolas, centros de assistência social, entre outras, que em sua maioria, são desenvolvidos em parcerias com as Secretarias de Educação e Cultura dos municípios vizinhos, ou então, em minicursos que são realizados na própria casa da artesã, quando procurada por pessoas que desejam aprender ou ter uma experiência com esse tipo de artesanato.

\section{Considerações Finais}

Relacionar os conceitos de patrimônio material, imaterial, identidade e memória cultural, sem dúvida é o resultado do amadurecimento e crescimento acerca das discussões do estado da arte da temática do patrimônio cultural. A compreensão holística desses termos nos possibilita um entendimento social abrangente, o que permite aplicar os recursos patrimoniais e tudo o que envolve essa dimensão em prol do reconhecimento e valorização das culturas populares, assim como contribuir para o seu desenvolvimento.

Através de atividades e esforços que almejam colocar em uma posição de destaque os debates acerca dos aspectos culturais das comunidades, pode-se contribuir na construção de comunidades que saibam reconhecer seus valores, onde o sentimento de pertencimento àquele grupo e território culminará em grupos mais criativos, cultural e socialmente emancipados.

Considerando como aspecto primário para a identificação e reconhecimento do patrimônio cultural de um determinado grupo social ou comunidade, no que se refere ao trabalho de valorização do saberfazer popular, por exemplo, tem-se o inventário cultural, mediante o uso de fichas de inventário como ferramenta de promoção da gestão e do planejamento do patrimônio cultural e de políticas sociais, econômicas e urbanas também. Mesmo que as políticas públicas sejam relativas, ou que priorizem uma parcela dos trabalhos voltados ao reconhecimento e salvaguarda do patrimônio cultural, entendese que a realização do inventário é por si só uma forma de valorizar e proteger um artefato.

Acredita-se que esse estudo, que apresentou parte da dimensão patrimonial cultural e do saber-fazer popular do recorte espacial adotado, contribui para a valorização e promoção interna do patrimônio, seja ele tangível ou intangível, utilizando da metodologia do inventariamento como parte desse conhecimento que merece cuidados. Considerando, especialmente, sua transmissão entre as gerações.

Destaca-se que essa é a primeira pesquisa que se deteve em uma análise sob a ótica patrimonial do município de Santo Antônio do Palma/RS a partir da leitura histórica. Esse artigo assume um papel de destaque, pois é o primeiro a registrar as memórias, histórias, assim como importantes acontecimentos ao longo dos anos dessa pequena municipalidade do interior gaúcho. Para tanto, acredita-se na importância de se desenvolver estudos e pesquisas acadêmicas tendo como recorte espacial pequenos territórios, visto que eles, com suas características e identidades, revelam dados interessantes para o debate. Estudar essas pequenas realidades culturais acerca das formações e transformações sociais, contribuem para a afirmação de uma identidade coletiva e da construção de novas memórias, ressignificando o patrimônio local, colaborando para compreendermos a dimensão dos artefatos materiais ou imateriais. Valorizar a identidade cultural implica em reconhecer o quão importante é para determinado grupo social. É a partir desse reconhecimento e valorização que se contribuirá para a conservação e salvaguarda dos valores, crenças, relações sociais, linguagens, ritos, cerimônias e tudo mais que possa pertencer àquela realidade cultural. 


\section{Agradecimentos}

À Coordenação de Aperfeiçoamento de Pessoal de Nível Superior (CAPES) pelo auxílio PROSUP concedido e ao grupo de pesquisas Cultural Heritage, Urbanistica e Sviluppo Localle.

\section{Referências}

ARAUJO, F. G. de. HAESBAERT, R. (Org.). Identidade territórios: questões e olhares contemporâneos. Rio de Janeiro: Access, 2007, pp. 33-56.

ASSMANN, Jas. Collective Memory and Cultural Identity. In: New German Critique. n. 65, Cultural History/Cultural Studies, (Spring-Summer, 1995), p. 125-133. Apud WEBER, Regina; MALTA, Elenita. Halbwachs e a Memória: contribuição à história cultural. Revista Territórios e Fronteiras, Cuiabá, v. 3, n. 1, p. 104-126, 2010.

AZEVEDO, Paulo Ormindo de. Inventário como Instrumento de Proteção: A Experiência Pioneira do IPAC-BAHIA. In: MOTTA, Lia; SILVA, Maria Beatriz Rezende (Org.). Inventários de Identificação: Um Panorama da Experiência Brasileira. Rio de Janeiro, RJ: Editora IPHAN, Ministério da Cultura, 1998.

BATISTA, Claudio Magalhães. Memória e Identidade: Aspectos relevantes para o desenvolvimento do turismo cultural. Caderno Virtual de Turismo, Rio de Janeiro, v. 5, p.27-33, mar. 2005.

CANANI, Aline Sapiezinskas Krás Borges. Herança, Sacralidade e Poder: Sobre as diferentes categorias do Patrimônio Histórico e Cultural no Brasil. Horizontes Antropológicos, Porto Alegre, v. 11, n. 23, p.163-178, jan/jun 2005.

CASTRIOTA, Leonardo Barci. Patrimônio Cultural: Conceitos, Políticas, Instrumentos. São Paulo: Annablume, 2009. $380 \mathrm{p}$.

EDELWEISS, Roberta Krahe. Cidade Contemporânea, memória e preservação patrimonial: uma interpretação a partir das preexistências culturais. Oculum Ensaios: Revista de Arquitetura e Urbanismo, Campinas, v. 1, n. 13, p.153-162, 08 set. 2016.

FERRÃO, André Munhoz de Argollo. Arquitetura Rural e o espaço não-urbano. Revista Labor \& Engenho, Campinas, v. 1, p.89-112, 2007.

FIGUEIREDO, Lauro Cesar. Perspectivas de análise geográfica do patrimônio cultural: algumas reflexões. Geografia Ensino \& Pesquisa, [S.I.], p. 55 -70, fev. 2013. ISSN 2236-4994.

FILIPPON, Maria Isabel. A Casa do Imigrante Italiano, a Linguagem do Espaço de Habitar. 2007. 153f. Dissertação (Mestrado em Letras e Cultura Regional) - Faculdade de Letras. Universidade de Caxias do Sul, Rio Grande do Sul.

FLORÊNCIO, S. R. R (et al). Educação Patrimonial: inventários participativos. Brasília: IPHAN, 2016.

GELATTI, Roque. Casca - Ontem e Hoje. Passo Fundo: Instituto Social P. Berthier, 1985.

GONÇALVES J. O patrimônio como categoria de pensamento. In: ABREU, Regina; CHAGAS, Mario (Org.). Memória e patrimônio. Rio de Janeiro: DP\&A, 2003. p. 21-29.

Inventário nacional de referências culturais: manual de aplicação. Apresentação de Célia Maria Corsino. Introdução de Antônio Augusto Arantes Neto. - Brasília: Instituto do Patrimônio Histórico e Artístico Nacional, 2000.

LEMOS, Carlos A. C. História da Casa Brasileira. São Paulo: Contexto, 1996. 
LEMOS, Carlos A. C. O que é patrimônio histórico. São Paulo: Brasiliense, 2013. Coleção Primeiros Passos; 51.

MANFROI, Olívio. (1975). Emigração e identificação cultural a colonização italiana no rio grande do sul. Estudos Ibero-Americanos, 1, 1975, p. 227-274.

MARADEI, Giovanna. Conheça Zalipie, cidade onde todas as casas têm flores pintadas à mão. 2017. Disponível em: <https://casavogue.globo.com/Arquitetura/Cidade/noticia/2017/02/conhecazalipie-cidadeonde-todas-casas-sao-pintadas-mao.html>. Acesso em: 28 abr. 2021.

MENESES, Ulpiano Toledo Bezerra de. A cidade como bem cultural. In: V. H. Mori, M. C. de Souza, R. Bastos, H. Gallo (orgs). Patrimônio: atualizando o debate. São Paulo: 9SR/IPHAN, 2006, p. 34-53.

NORA, Pierre; AUN KHOURY, Tradução: Yara. ENTRE MEMÓRIA E HISTÓRIA: A problemática dos lugares. Projeto História: Revista do Programa de Estudos Pós-Graduados de História, [S.I.], v. 10, out. 2012. ISSN 2176-2767.

PEIXOTO, Paulo. Tudo que é Sólido se Sublima no Ar: Políticas Públicas e Gestão do Patrimônio. In: CYMBALISTA, Renato; FELDMAN, Sarah; KÜHL, Beatriz M. (Org.). Patrimônio Cultural: Memória e Intervenções Urbanas. São Paulo: Annablume, 2017. P. 17.

POLLAK, Michael. Memória, esquecimento e Silêncio. In. Estudos Históricos. 1989/3. São Paulo. Cpdoc/FGV.

RINDOS, Irena. WYCINANKI: prduction of a non-photorealistic rendered short film. 2012. $37 \mathrm{f}$. Monografia (Especialização) - Curso de Master Degree Of Fine Arts Digital Production Arts, Clemson University, Clemson, 2012.

SANTOS, Roselys I. Correa \& ANTONINI, Bianca Oliveira. LA GASTRONOMIA TÍPICA DE LA ISLA DE SANTA CATARINA - Brasil: Su identidade como atrativo para el turismo cultura. In. Estudios y Perspectivas en turismo. Vol.13. Números 1 y 2 2004. Centro de investigaciones y Estudios Turísticos. Buenos Aires. Argentina.

SCHNEIDER, Luiz Carlos; FIALHO, Daniela Marzola. Identidade, Território e Paisagem no Contexto do Ordenamento Territorial. In: VII SEMINÁRIO INTERNACIONAL SOBRE DESENVOLVIMENTO REGIONAL, 2015, Santa Cruz do Sul. Anais do VII Seminário Internacional sobre Desenvolvimento Regional. Santa Cruz do Sul.

TEDESCO, João Carlos; BALBINOT, Giovani. Carretas e carreteiros na Colônia Guaporé, nordeste do RS, no período de 1892-1960. Revista de História Regional, Ponta Grossa, v. 19, p.408-436, 2014.

UNESCO. Convenção para Salvaguarda do Patrimônio Cultural Imaterial. Paris: Unesco, 2003.

VARINE. Hugues de. As raízes do futuro: O patrimônio a serviço do desenvolvimento local. Tradução de Maria de Lourdes Perreiras Horta. Porto Alegre: Medianiz, 2012.

WEBER, Regina; MALTA, Elenita. Halbwachs e a Memória: contribuição à história cultural. Revista Territórios e Fronteiras, Cuiabá, v. 3, n. 1, p. 104-126, 2010. 


\section{Adilson Giglioli}

Arquiteto e Urbanista pela Universidade de Passo Fundo - UPF (2018), Mestre em Arquitetura e Urbanismo pela Faculdade Meridional - IMED (2021), discente do programa de Pós-Graduação Lato Sensu em Docência para o ensino superior pela Universidade de Caxias do Sul - UCS (2021 - em andamento). Pesquisador na área de ecomuseus, patrimônio cultural, desenvolvimento local e regional. Atua como arquiteto autônomo e arquiteto consultor da Associação de Turismo da Serra Nordeste Uva e Vinho - ATUASERRA.

Contribuição de autoria: Concepção; Curadoria de dados; Análise; Coleta de dados; Metodologia; Software; Supervisão; Validação; Visualização; Redação - rascunho original; Redação - revisão e edição.

\section{Dirceu Piccinato Junior}

Possui Graduação em Arquitetura e Urbanismo pelo Centro Universitário Moura Lacerda (CUML-2001) e em Filosofia pelo Centro Universitário Claretiano (CEUCLAR-2008), mestrado em Urbanismo pela Pontifícia Universidade Católica de Campinas (PUC Campinas-2012), doutorado em Urbanismo pela Pontifícia Universidade Católica de Campinas (PUC Campinas-2016) com estágio de pesquisa na Universidade do Algarve (UAlg, Portugal-2015). Atualmente é Docente dos Programas de Graduação e Pós-Graduação Stricto Sensu em Arquitetura e Urbanismo da IMED (IMED-PPGARQ); Bolsista de Produtividade da Fundação Meridional (2018-2021) e Pesquisador integrante do Grupo de Pesquisa Teoria e História da Habitação e da Cidade (THAC-IMED). Atua nas áreas de Planejamento Urbano e Regional e Projeto em Arquitetura e Urbanismo, com ênfase em Fundamentos da Arquitetura e Urbanismo e Teoria e História da Arquitetura e do Urbanismo.

Contribuição de autoria: Concepção; Curadoria de dados; Metodologia; Supervisão; Redação - rascunho original.

\section{Henrique Aniceto Kujawa}

Doutor em Ciências Sociais pela UNISINOS (2014), Mestrado em História pela Universidade de Passo Fundo (2000), graduação em História pela Universidade de Passo Fundo (1994). Docente do Programa de Pós Graduação em Arquitetura e Urbanismo da IMED, desde 2017. Docente da Graduação dos Cursos de Direito, Psicologia e Arquitetura e Urbanismo na IMED, desde 2005. Docente Universidade de Chapecó- UNOCHAPECÓ (2001-2017). Bolsista produtividade de Pesquisa da Fundação Meridional, desde 2017. Membro do Grupo de Pesquisa Teoria e História da Habitação e da Cidade (THACIMED) e do Centro Brasileiro de Pesquisa sobre a Teoria da Justiça de Amartya Sen. Tem experiência na área de História e Ciências Sociais, atuando principalmente nos seguintes temas: direito humano à saúde, movimentos sociais, território e territorialidade, políticas habitacionais, patrimônio cultural e desenvolvimento, tramas sociais e constituição de espaços urbanos.

Contribuição de autoria: Supervisão; Redação - rascunho original.

Como citar: GIGLIOLI, Andilson, JUNIOR, Dirceu Piccinato, KUJAWA, Henrique Aniceto. O inventário como ferramenta de reconhecimento e preservação do patrimônio cultural das comunidades rurais de Santo Antônio do Palma/RS, Brasil. Revista Paranoá.n.32, jan/jun 2022. DOI 10.18830/issn.16790944.n32.2022.01

Editoras responsáveis: Maria Fernanda Derntl, Carlos Henrique Magalhães de Lima e Carolina Pescatori. 